Journal of

Strategic Management

(JSM)

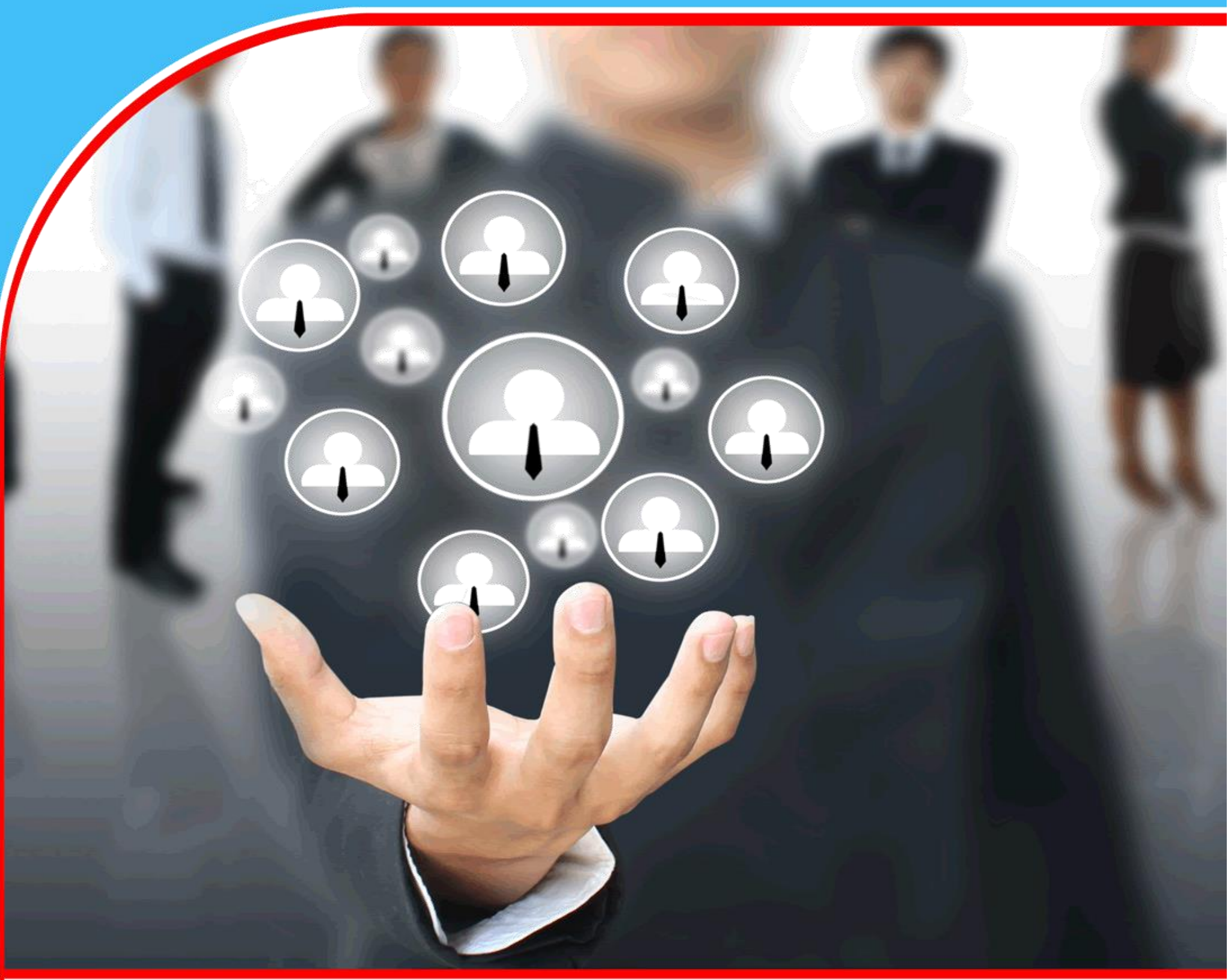

STRATEGIC LEADERSHIP AND STRATEGY IMPLEMENTATION IN COMMERCIAL BANKS IN KENYA

Mr. Habil Olaka, Prof. Peter Lewa and Dr. Peter Kiriri

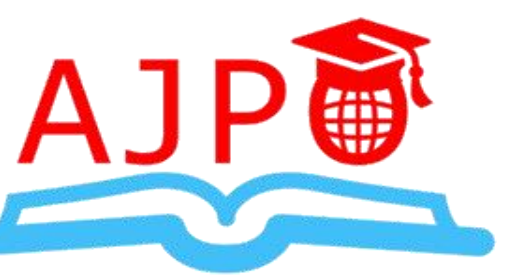




\title{
STRATEGIC LEADERSHIP AND STRATEGY IMPLEMENTATION IN COMMERCIAL BANKS IN KENYA
}

\author{
${ }^{1}$ Mr. Habil Olaka \\ DBA Student at United States International University (USIU), Nairobi, Tel +254722860655 \\ email: Holaka@kba.co.ke (Corresponding author) \\ ${ }^{2}$ Prof. Peter Lewa
}

Professor at United States International University (USIU), Nairobi, Tel +254722867213 , email: lewapm@usiu.ac.ke

${ }^{3}$ Dr. Peter Kiriri,

Professor at United States International University (USIU), Nairobi, Tel +254722988777 , email:pnkiriri@usiu.ac.ke

\begin{abstract}
Purpose: The general objective of this study was to investigate the influence of strategic leadership on the implementation of strategy in the commercial banks in Kenya. The seven critical components of strategic leadership studied were strategic direction, core competencies, human capital, social capital, corporate culture, ethical practices and strategic controls. More specifically, the study investigated the influence of these components on the implementation of strategy in the commercial banks in Kenya.

Methodology: The study adopted a quantitative research design whose target population was the top management team in the commercial banks in Kenya. The instrument of data collection was tested for reliability using the Cronbach alpha test and for validity using the KMO and Bartlett's test. Statistical analysis was then carried out on the data collected.

Findings: The study finds that there is a positive statistically significant relationship between effective implementation of strategy with only two of the strategic leadership actions which are 'determining strategic direction' and 'establishing balanced organization controls'. The study recommends that the leadership and in particular the CEO to focus his energies on providing the strategic direction of the organization if it is to achieve its strategic objectives of remaining competitive in the market. Similarly establishing a balance between strategic and financial controls has a direct influence on the implementation of strategy. A strategic leader creates wealth by striking a balance between the constraining influence of financial controls and the long term focus of the strategic controls.
\end{abstract}

Key words: strategic leadership, strategy implementation, strategic direction, resource portfolio, organizational culture, ethical practices, organizational controls 


\subsection{INTRODUCTION}

\subsection{Background of the Study}

Leadership and strategic management are two widely studied areas in academic literature but there has not been as much focus on how the two fields combine to influence the performance of business entities. In the realm of strategic management, there is more work done on strategy formulation than on the implementation and control aspects of strategy (Hrebiniak, 2006). Strategic management encompanses the full set of commitments, decisions, and actions that result in the formulation and implementation of plans that required for a firm to achieve strategic competitiveness and earn above average returns (Pearce \& Robinson, 2011; Hitt, Ireland \& Hoskisson, 2013). Strategic leadership can be defined as a person's ability to participate, envision, maintain flexibility, think strategically and work with others to initiate changes that will create a viable future for the organisation (Lussier \& Achua, 2007). Strategic leadership drives the organization towards coping with change by guiding the organization to deal with change or by providing the management skill to cope with the ramifications of constant change (Pearce \& Robinson, 2011). Strategic leadership when effective helps develop organisation goals and then drives performance to ensure that the goals are achieved.

Research work has shown that failure is more attributable to strategy implementation than to its formulation yet effort in academia and business schools has focussed on strategy formulation than on implementation of the strategy partly promoted by the view that one learns the formulation of strategy in class and experiences the implementation in practice by doing (Hrebiniak, 2006).

Various strategy implementation frameworks have been proposed by researchers and most of them are based on the concept of fit. Organisation strategy cannot effectively be implemented unless there is consistency between the strategy and each of the other organisation dimensions i.e. structure, people,process, task etc. Most of the other strategy implementation frameworks have been based on the need for alignment between the strategy and other organisational dimensions. The McKinsey 7-S Framework is a model known as the seven elements of strategic fit and highlights the integration of implementation with other strategic management components. The 7 elements are strategy, structure, systems, skills, shared values, staff, and style.

Leadership appears as a common variable for the effective implementation of strategy in all these frameworks that have been developed for strategy implementation. Strategic leadership has been identified as a key driver to strategy implementation and the lack of it has similarly been identified as a barrier to strategy implementation (Bossidy \& Charan, 2002; Hrebiniak, 2006; Kaplan \& Norton, 2001). Strategic leadership when effective helps develop organisation goals and then drives performance to ensure that the goals are achieved. 
According to Hitt, Ireland, \& Hoskisson (2013), the seven critical identifiable actions that characterise strategic leadership that positively contribute to strategy implementation are (1) Determine strategic direction: vision and strategic intent, (2) Exploiting and maintaning core competencies, (3) Developing human capital, (4) Developing social capital, (5) Sustaining an effective organizational culture, (6) Emphasizing ethical practices, and (7) Establishing balanced organizational goals.

Each of these actions contribute to the effective implementation of the strategy and it is evident that strategic leaders are involved in each of the actions. Strategic leadership is therefore central to the effective implementation of strategy.

The banking sector in Kenya has shown relatively steady performance on most measures of performance from return on assets, return on equity, net interest margin, growth in assets, growth in deposits, growth in profitability (CBK, 2015d). The sector witnessed a period of bank failures in waves with the first wave in 1986-1989, then in 1993-1994 and latest in 1998 (Waweru \& Kalani, 2009). The period after year 2000 witnessed good performance by the banking sector which until year 2015 had no reported bank failure. However in 2015 and 2016, three banks were put under receivership by the Central Bank of Kenya for reasons that were attributed to deterioriation in the financial condition of the banks for different reasons but all pointing to failure in corporate governance in the institutions. The Annual Bank Supervision Reports of the Central Bank of Kenya (CBK, 2015d) indicate that poor performance amongst peers has generally been low. Looking at banks in Kenya, the Annual Reports of the Bank Supervision Department of the Central Bank of Kenya (CBK, 2017) show a fairly stable performance trend for the period after year 2000 till 2015.

Whereas the performance could be attributable to regulatory measures that have been put in place since the banking sector's challenging periods of 1980s and 1990s, it could also be attributable to effective strategy implementation in the commercial banks.

This study was carried out on the commercial banks in Kenya and the questionnaire respondents were the top level management staff who are considered to be directly responsible and involved in the strategy implementation process in the commercial banks.

\subsection{Research Problem}

Strategy implementation is a key component of the strategic management process. There is a lot more effort and resources invested by organizations in the formulation process than the implementation and control of strategy (Hrebiniak, 2006). Failure rates reported are attributable to failure in the strategy implementation. Various sources have reported implementation failure rate above 60\% (Nohria \& Beer, 2000; Mankins \& Steele, 2005; Allio, 2005; Candido \& Santos, 2015). The high failure rate is nonetheless a pointer to the fact that 
implementation of strategy is not an easy task and one of the key drivers to effective strategy implementation is the existence of strategic leadership in the organization (Lussier \& Achua, 2007). The studies on the relationship between strategic leadership and strategy implementation done by Fourie (2007) and Lear (2012) in South Africa, Mapetere et al. (2012) in Zimbabwe, Rajasekar (2014) in Sultanate of Oman, Cater \& Pucko (2010) in Slovenia, and by Kuchio (2012) and Sila \& Gichinga (2016) in Kenya did not focus on the banking sector and more so in the Kenyan context which was the case in this study.

The banking sector in Kenya has registered comparatively good performance compared to other sectors and even in comparison to the banking sector performance in the EAC member countries from the perspective of most measures of performance. Whereas the performance could be attributable to regulatory measures that have been put in place since the banking sector's challenging period of 1980s and 1990s, the other contributory factor could be effective implementation of strategy in the individual banks.

Prior studies (Fourie, 2007; Lear, 2012; Kuchio, 2012) have tested the positive relationship between strategic leadership and strategy implementation but to the knowledge of the researcher this relationship has not been empirically investigated in relation to commercial banks in Kenya. The study is to establish the extent of the relationship between the strategic leadership criteria and strategy implementation in commercial banks in Kenya. The target population comprise the top level management who are viewed as the ones directly involved in the implementation of strategy in the commercial banks in Kenya.

\subsection{Research Objective}

The general objective of this research was to investigate the influence of strategic leadership on the effective implementation of strategy in the commercial banks in Kenya. The specific objectives were to investigate the influence of each of the seven criteria of strategic leadership on the effective implementation of strategy in commercial banks in Kenya.

\subsection{LITERATURE REVIEW}

\subsection{Theoretical Frameworks}

The earliest leadership theory, in late $19^{\text {th }}$ to mid- $20^{\text {th }}$ century, the trait theory focused on differing categories of traits or characteristics possessed by leaders believed to be causal in the performance of leaders (Sanders \& Davey, 2011). Dissatisfaction with the traits theory led to behavioral theories (House \& Aditya, 1997) that focused on what leaders did to actuate results, as the causal agent in influencing followers, but did not explicitly reject a reciprocal relationship. While these behavioral theories substantially improved explanation and prediction of leadership outcomes, situational elements were not adequately captured, particularly for identifying leader behaviors most effective in particular situations, hence the emergence of contingency theories (House \& Aditya, 1997). In the contingency theories, the 
contingency variables in a particular situation serve as moderators of leader behaviors to increase leader effectiveness. Contemporary theories of leadership primarily deal with organizational changes extending transactional theories beyond leader-subordinate exchange process to incorporate change of the follower hence change of organization (Sanders \& Davey, 2011).

Boal and Hooijberg (2000) discuss the evolution of strategic leadership theories in the following categories: upper echelons theory, new leadership theories (charismatic, transformational and visionary) and the emergent theories of leadership. House and Aditya (1997) indicate the shift in mid 1980's away from the study of supervisory leadership towards the study of strategic leadership initially centering on the Upper Echelon Theory (Hambrick \& Mason, 1984) and the study of top management teams and the new leadership theories. Supervisory theories of leadership focus on task- and person-oriented behaviors of leaders while strategic leadership theories focus on the creation of meaning and purpose for the organization (House \& Aditya, 1997).

\subsubsection{Upper Echelon Theory}

The Upper Echelon Theory is attributed to a seminal paper presented by Hambrick and Mason in 1984 which states that strategic choices and business performance are dependent on the characteristics of dominant actors within an organization and in particular the top management team. The theory suggests that organizations are reflections of the top management team's cognition and values and organizational outcomes - strategic choices and performance levels are partially predicted by managerial background characteristics i.e. reflection of the values and cognitive bases of powerful actors in the organization. The theory argues that individual psychological factors and observable experiences affect strategic choices, which in turn, affect performance (Finkelstein \& Hambrick, 1990). The amounts of discretion enjoyed by the top management team will moderate the relationship between strategic choices and organizational outcomes, where the more discretion, the greater the impact of choice on the outcomes (Boal \& Hooijberg, 2000; Elenkov, Judge \& Wright, 2005)

Upper Echelons Theory has been criticized for not directly studying actual strategic leadership behavior. Priem, Lyon, \& Dess (1999) raise issues on the use of demographic indicators as proxy for strategic leadership behaviors. Data on demographic characteristics is easy to collect hence the temptation to use it as proxy. Despite awareness of limited usability of demographic proxies for strategic leadership, there is still no alternative theoretically derived measure for strategic leadership (Duursema, 2013).

Most studies on upper echelons theory have been conducted in western, developed (predominantly the United States) economies and it is thus unknown and relatively unexplored just how strategic leadership behaviors vary throughout the rest of the world. The upper echelons perspective has provided good theoretical and some empirical arguments for the central role of strategic leadership but our understanding is still lacking in significant ways (Elenkov et al., 2005). 


\subsubsection{Strategic Leadership Theory}

Strategic leadership theory was developed and expanded from Hambrick and Mason's (1984) Upper Echelons Theory with the aim of examining how the top managers influence strategic decision-making (Finkelstein \& Hambrick, 1996). This study is anchored on the Strategic Leadership Theory as it studies how the top leadership influence strategic decisions such as those that lead to the effective implementation of strategy in the commercial banks. Carter and Greer (2013) indicate that a significant amount of scholarly work over the past 30 years has been devoted to the analysis and comparison of different leadership styles, much of which has dealt with transactional, transformational and charismatic leadership, with more recent work beginning to address styles and approaches such as servant, authentic, and responsible leadership giving insights into the influence of leadership styles on performance outcomes. It is argued that little of this research has been conducted in the context of strategic leadership and instead has focused on leadership styles of lower level managers and the influence of the leadership styles on the performance of the team units within the organization and not the overall organization performance in meeting stakeholder expectations. They indicate the paucity of research on the relationship of strategic leadership with organizational performance (Carter \& Greer, 2013).

The new leadership theories focus on the charismatic, transformational and visionary leadership theories and tend to highlight the interpersonal processes and relationships between the leader and the follower (Boal \& Hooijberg, 2000). Hitt et al. (2013) view transformational leadership as a style of strategic leadership and even consider it as the most effective strategic leadership style, which entails motivating followers to exceed expectations, continuously enriching their capabilities and placing the organization's interest above their own. Transformational leaders develop and communicate a vision and formulate strategies to achieve the vision by continuously encouraging followers to strive for higher levels of achievement (Hitt et al., 2013).

Rowe (2001) notes that managerial leadership involves stability and order, and the preservation of existing order such that managerial leaders are more comfortable handling day-to-day activities while being short term oriented. Managerial leaders have an impersonal, passive attitude towards goals as they arise out of necessity rather than desires or dreams and deeply embedded in the history and culture of the organization (Zaleznik, 1992). Managerial leaders need order, not the chaos characterisitc of human relations and see themselves as responsible for conservation of current state of organization's affairs and order, and are sensitive to the past. Managerial leadership can be likened in some ways to transactional leadership and does not create wealth, as they at best maintain the wealth created but may be a source of wealth destruction in the long term if they are the predominant leadership type (Rowe, 2001) .

Visionary leaders, in contrast, are more proactive in shaping ideas and usually exert influence in a way that determines the direction the organization takes, working with high risk positions, seeking out risky ventures especially when the rewards are high. Visionary leadership is future oriented, concerned with risk taking and visionary leaders are not dependent on the organization for their sense of who they are and more likely to make decisions based on values. Visionary leaders maintain organization control through socialization and the sharing of, and compliance with, a commonly held set of norms, values and shared beliefs (Rowe, 2001). 
They work in, but do not belong to, organizations as their sense of who they are does not depend on their work, role, or membership but on their created sense of identity, which may result from major events in their lives (Zaleznik, 1992). Organizational control is maintained through sharing of and compliance with a commonly held set of norms, values and shared beliefs, in some sense similar to the inspirational component of transformational leadership (Rowe, 2001).

Organizations led by visionary leadership to the exclusion of managerial leadership are more in danger of failing in the short term than those led by managerial leaders and proposes the solution to be a combination of managerial leaders and visionaries to lead organizations with visionaries having more influence than managerial leaders (Kotter, 2001). It is even better to have an individual who can exercise both managerial and visionary leadership. Rowe (2001) puts a case for strategic leadership where the two organizational mindsets (managerial and visionary) co-exist but with visionary being more influential than managerial and argues that an organizational will be more viable in the long run and better able to maintain its financial stability in the short term, if strategic leadership is privalent in the organization. Strategic leaders are identified as a synergistic combination of a managerial leader (who never stop to dream) and visionaries (who only dream) in that they dream and do something about their dreams and argues that a strategic leader would probably create more wealth than a combination of a visionary leader and a managerial leader because the synergistic combination enhances the long term viability while maintaining the short term financial stability.

Strategic Leadership Theory has been criticized for not directly studying actual strategic leadership behavior. Priem et al. (1999) raise issues on the use of demographic indicators as proxy for strategic leadership behaviors. Data on demographic characteristics is easy to collect hence the temptation to use it as proxy. They argue that most studies linking strategic leadership behaviours (independent variable) to performance (dependent variable) have used demographic characteristics for strategic leadership behaviors and these are limited by the instrinsic trade-offs which sacrifice construct validity for measurement reliability. These fundamental questions about the meaning and construct validity of the use of demographic variables in strategic leadership theory led Boal and Hooijberg (2001) to question whether, in its current form, strategic leadership theory should even be considered a theory of strategic leadership. Despite awareness of limited usability of demographic proxies for strategic leadership, there is still no alternative theoretically derived measure for strategic leadership (Duursema, 2013).

\subsection{Conceptual Framework : Strategic Leadership in Effective Implementation of Strategy}

The conceptual framework shows the relationship between the dependent variable and the independent variables. Effective implementation of strategy which entails the attainment of the strategic objectives is the dependent variable, while the seven critical actions that characterize strategic leadership will comprise the independent variables. In addition, there are other factors which are not within the control of the leaders but which none the less affect the dependent variable, and these are identified as moderating variables. 
The dependent variable essentially entails the attainment of the strategic objectives the firm sets out to achieve. Attainment of strategic objectives can be measured using the Balance Scorecard metric which combines four perspectives (financial, customer, internal processes and innovation and ornwth) to facilitate measurement of performance. The Balanced Scorecard Indenendent Variables icial performance with measures on drivers, the lead indicators of future financial performance. The Balanced Scorecard includes financial

Strategic Direction
performance (Kaplan \& Norton, 1992).

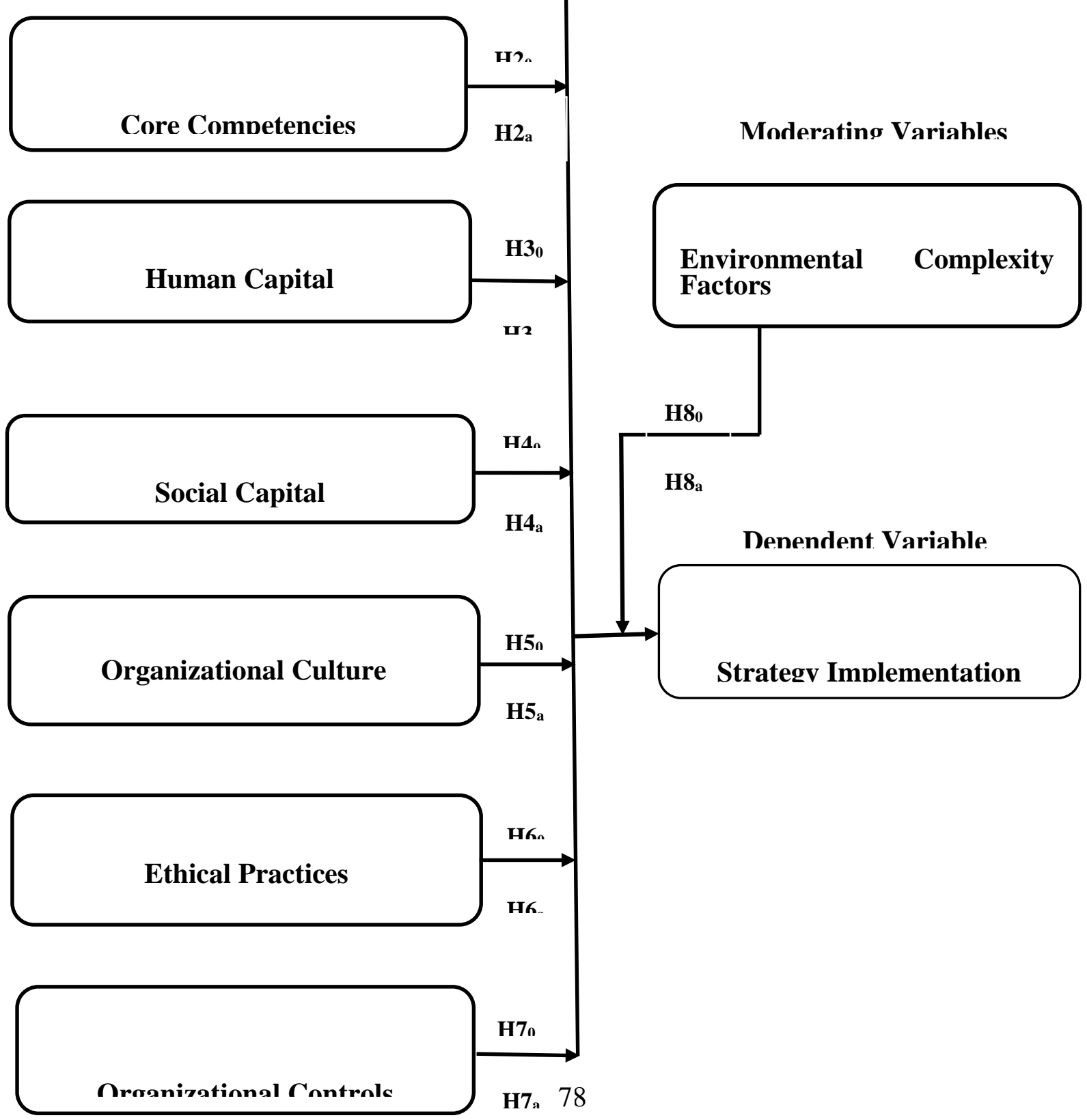


The Balanced Scorecard allows managers to look at a business from four perspectives namely: financial (concerned with profitability, growth and shareholder value), customer (concerned with how the company's products or services contribute to creating value for the customer), internal business processes (concerned with priorities for the various processes that create customer and shareholder satisfaction), and learning and growth (concerned with the firm's creation of a climate that supports change, innovation and growth) (Kaplan \& Norton, 1992).

The seven independent variables are: determining the strategic direction, exploiting and maintaining core competencies, developing human capital, developing social capital, sustaining an effective organizational culture, emphasizing ethical practices and establishing balance in organizational goals.

\subsubsection{Dependent variable: effective implementation of strategy}

Whereas strategy formulation has enjoyed some focus from the organizational leadership over its implementation, it is acknowledged that most strategies fail not because of the formulation but for failure at the implementation stage (Kaplan and Norton, 2001). A well formulated strategy must take into account the means by which it would be implemented and it is only through implementation that a strategy can be refined and reformulated (Grant, 2008).

Performance evaluation and the subsequent rewarding of performance can be a powerful tool for effective strategic implementation (Ehlers and Lazenby, 2004). A number of performance measurement systems have been developped incorporating financial and non-financial measures. The Balanced Scorecard is one such performance measurement that creates a balance between external measures for shareholders and customers, and internal measures of critical busines processes, innovation, and learning and growth, and has gone beyond being an operational measurement system to a strategic management system. Management processes built around the score card create an allignment and focus on implementation of the long-term strategy (Kaplan \& Norton, 1996).

\subsubsection{Independent variables: Critical criteria of Strategic leadership}

\section{a) Determining the strategic direction: vision and strategic intent}

Determining strategic direction involves specifying the vision and the strategies to achieve the vision over time and is framed within the context of the conditions strategic leaders expect their firm to face in the next 3 to 5 years. The strategic direction specifies the image and character the firm wants to develop over time (Hitt et al., 2013). Studies by Hagen et al. (1998) and by Korn/Ferry International/Columbia University (Bass, 2007) indicate the outcome from surveys that ranked 'determining strategic direction' as the most important strategic leadership role.

Lipton (1996) states that vision must focus on the future and serve as a concrete foundation for the organization and unlike goals and objectives, a vision does not fluctuate from year to year 
but serves as an enduring promise painting a vivid picture for the organization (Lipton, 1996). Herrmann and Nadkarni (2014) contend that CEO personality will determine both initiation of strategic change and the performance effects of strategic change implementation. Personality shapes how CEOs communicate with, reward, motivate and mobilize proximal employees who can decide the success or failure of strategy implementation. Strategic change is achieved through the contributory efforts of the top managers but also the employees contribute to the achievement of new strategic direction by adapting to change facilitated by meaning-making process in the employees (Sonenshein \& Dholakia, 2012).

At times, the top management team and in particular the CEO are so committed on the status quo due to an aversion to what they consider as risky actions. Such behaviours are not consistent with high performing organizations and may even lead to change in the leadership at the CEO level (Hitt et al., 2013).

\section{b) Exploiting and maintaining core competencies}

Core competencies are capabilities that serve as a source of competititve advantage for a firm over its rivals, which are developped over time as firms learn from the results of the competitive actions and responses taken during the process of competing with rivals (Hitt et al., 2013). Exploting core competencies involves sharing resources across units in the organization, a role that typifies effective strategic leaders. The core competencies based on intangible resources are most effective because they are less visible as they relate to employees' knowledge and skills (Lear, 2012).

Srivastava (2005) notes that possession of core competencies, which are typically built up overtime, is not an end in itself and the ability to leverage core competencies for the benefit of the firm is more important. Resources can influence performance only to the extent that a firm can adequately leverage them, and what a firm does with its resources is just as important to performance as its possessing those resources (Ndofor, Sirmon, \& He, 2011). RBV suggests that possessing valuable, rare, inimitable, and non-substitutable resources leads to creation of value sustainably or competitive advantage but merely possessing such resources does not guarantee development of competitive advantage or creation of value, in which case firms must accumulate, combine, and exploit the resources (Sirmon, Hitt, \& Ireland, 2007).

Strategic leaders must ensure that the firm's core competencies are understood when selecting strategies at the strategy formulation stage and then emphasized when implementing the selected strategies (Hitt et al., 2013). Strategic leaders must allocate resources towards building new capabilities, which capabilities are developped into core competencies. Core competencies are developed and used through human capital and social capital which are critical resources for a firm's success (Hitt et al., 2013). These resource are here below discused.

\section{c)Developing human capital}


Human capital refers to the knowledge and skills of a firm's entire workforce. From the perspective of human capital, employees are viewed as a capital resource requiring continuous investment, being perhaps the only truly sustainable source of competitive advantage. In every organization the human capital's increasing importance implies a significant role for the human resource function of the organization (Hitt et al., 2013). Hitt et al. (2006) support the argument that valuable intangible resources are the most likely to contribute to a competitive advantage and create value for owners, extending the knowledge of the resource based view of the firm (RBV). RBV suggests that possessing valuable and rare resources provides the basis for value creation, which may be sustainable when the resources are also inimitable and lack substitutes (Sirmon, Hitt, \& Ireland, 2007). Firm's resources, in particular those that are valuable, rare, and inimitable, can be used as a basis for and as an aid to implementing strategies that can create a competitive advantage. The interaction of human capital with strategy has positive effects on firm performance which shows a positive moderating effect of human capital on the firm's performance (Hitt et al., 2001). Mere possession of these resources does not guarantee development of competitive advantage or the creation of value. To realise value creation firms must accumulate, combine and exploit the resources (Grant, 1991).

Effective staff development and training programs increase the likelihood of developing some of the firm's human capital into strategic leaders (Hitt et al., 2013). The programs help strategic leaders build skills to complete other tasks associated with the actions characteristic of strategic leadership, such as determining strategic direction, exploiting and maintaning core competencies, developing an organizational culture that supports ethical practices, hence the assertion that building human capital is essential for the effective execution of strategic leadership (Hitt et al., 2013).

\section{d) Developing social capital}

Social capital is the goodwill available to individuals or groups whose source lies in the structure and content of the actor's social relations and its effects flow from the information, influence, and solidarity it makes available to the actor (Adler \& Kwon, 2002). Hitt et al. (2013) indicate that it involves relationships inside and outside the firm that helps in efforts to accomplish tasks thereby creating value for the stakeholders. It is a critical asset given the need to cooperate both within and externally to be able to accomplish tasks. Multinationals need to establish alliances to enter new markets, entrepreneurial firms establish alliances to access resources, venture capital and other resources they cannot afford to maintain in-house (Hallen $\&$ Eisenhardt, 2012). Managerial ties - the boundary-spanning ties and interpersonal connections of top managers - have vital influences on a corporation's activities and may be a source of competitive advantage and superior performance (Gao, Xu, \& Yang, 2008). Managerial ties make corporations more informed and flexible and by using the data so obtained and investing in absorptive capacity, this induces motivation for innovation leading to improved corporate performance. 
Relational capital refers to the joint benefits embedded in a relationship between two or more parties that is highly important to those parties (Dyer \& Singh, 1998). Dyer \& Singh (1998) contrast viewpoints on sources of competitive advantage being Porter's industry structure view and the resource-based view (RBV) and add a third - relational view focusing on network routines and processes for competitive advantage in which relational rents are jointly generated and owned by partnering firms that use inter-organizational strategy to establish relations that create value that would otherwise not be created by either firm independently. Hitt et al. (2006) found that corporate client relational capital only serves as a base for internationalization and hence positive firm performance when a firm has a strong human capital.

\section{e) Sustaining effective organization culture}

Organizational culture is defined as a complex set of values, beliefs, assumptions, and symbols shared throughout the firm that define ways in which a firm conducts its business (Barney, 1986; Hitt et al., 2013). Shaping the context within which organizations formulate and implement strategies, and that is shaping the organization culture is an important strategic leadership action. Organizational culture can encourage or discourage leaders from pursuing entrepreneurial opportunities, which are a vital source of growth and innovation. Strategic entrepreneurship is effective only when the employees have an entrepreneurial orientation or mind-set (Hitt et al., 2013).

Intangible resources are more likely than tangible resources to confer a competitive advantage because they tend to be rare and difficult to imitate with socially complex resources, such as culture, being the most unique of all. Managers therefore need to tailor their practices into a culture that complement the chosen strategy (Klein, 2008). Cultural norms have a fairly consistent impact on quality and hence performance irrespective of the organizational strategy.

Shared assumptions about the organization's core mission (which defines the organization's culture) can limit not only the strategy but also the vision, thus one of the basic elements in leadership roles i.e. establishing vision, is inhibited unless the organization's culture encourages strategic thinking (Goldman \& Casey, 2010). Building a culture that supports and encourages strategic thinking is a significant endeavour that draws on personal, interpersonal, and organizational resources, hence directly influenced by the executive.

An organizational culture can encourage (or discourage) strategic leaders and their coleagues from pursuing entrepreneurial opportunities which are a vital source of growth and innovation. Strategic leaders therefore encourage and promote innovations by pursuing entrepreneurial opportunities (Hitt et al., 2013). Besides the top leaders, managers have significantly more impact on effecting change and hence firm performance than individual innovators by integrating and coordinating the innovative work of others and energizing the culture and fostering alignment with the organization's vision and mission (Mollick, 2012; Hitt et al.,2013).

\section{f) Emphasizing ethical practices}

Ethical companies enable staff at all levels act ethically at the strategy implementation stage which in turn creates social capital in the organization. Arnaud and Schminke (2012) observe that the collective moral reasoning reflected in ethical climate will translate into ethical 
behaviour when the work unit members exhibit collective moral emotions and the group is enabled by collective ethical efficacy to act in accordance with that reasoning. On the other hand when unethical practices evolve they may become acceptable and individuals more likely to engage in unethical practice to meet their goals when current efforts to meet them are insufficient (Hitt et al., 2013).

A value-based culture ensures that employees comply with the firm's ethical standards. Pearce (2013) finds that the strength of a manager's emphasis on legal and ethical values relates to the importance that the manager places on the business decision under evaluation. Developping such a culture (value-based) is challenging for multinational corporations which are globally spread and requires constant nurturing and support (Hitt et al., 2013).

When firms have lax expectations in place for individuals to follow in terms of ethical behaviour, leaders may tend to act opportunistically and make decisions that are in their own best interests, and not necessarily the organisation's (Hitt et al., 2013). Schwartz (2013) argues that in order to minimize illegal or unethical activity in a firm, firms must have a set of core ethical values, establish a formal ethics program, and have ethical leadership that sets an appropriate 'tone at the top' and these three elements though distinct, they also overlap, relate to, and reinforce each other (Schwartz, 2013) and the effectiveness of the actions increase when they are taken simultaneously and hence mutually supportive (Hitt et al., 2013).

\section{g) Establishing balance in organizational goals/strategic controls}

Organization controls guide the use of strategy facilitating the comparison between actual results to the expected results and suggesting the corrective action to take when the difference is unacceptably high. When properly designed these organization controls provide a spot light on behaviors to be supported to enhance the firm's performance. Hitt et al. (2013) defines controls as the formal, information based procedures used by managers to maintain or alter patterns in organizational activities. Organizations use both strategic controls and financial controls to support the implementation of their strategies.

Strategic controls are mainly based on subjective criteria whose purpose is to verify that the firm is using the appropriate strategies given the conditions in the external environment and the firm's core competences hence competitive advantage, and help the organization change course especially when a strategic change is needed (MacKay \& Chia, 2013).

Financial controls are mainly based on objective criteria and used to measure the organization's performance against quantitative standards that have been put in place. A Common financial controls is the accounting measure, the return on assets (ROA). The organization is structured to employ both the strategic controls and financial controls and it is the combination and striking the balance that makes the structure most effective (Hitt et al., 2013; Kim et al., 2013). The Balance Scorecard (BSC) is used to achieve the kind of balance that is required to achieve higher levels of performance (Hitt et al., 2013). A strategic leader creates wealth by fighting against the constraining influence of financial controls and fighting for the exercise of strategic and financial controls, with the emphasis on the strategic controls (Rowe, 2001). 


\subsection{RESEARCH METHODOLOGY}

From the philosophical worldviews, this research falls in the category of positivism which emphasizes objectivist approach thus giving prominence to research methods that focus on quantitative analysis (Mkansi \& Acheampong, 2012). Quantitative research approach was appropriate for this study as it involves systematic collection, statistical analysis of the data and the development of an analytical framework (Saunders, Lewis, \& Thornhill, 2014). This study was aimed at empirically examining the relationship between measurable variables using a validated measurement instrument.

This study used the descriptive design in which the study was concerned with learning why i.e. how one variable produced changes in another and essentially tried to explain the causal relationships amongst variables (Cooper \& Schindler, 2014). As opposed to experimental study where the aim is to establish causality, this study was descriptive/observational. Descriptive design was selected because the study aimed at establishing the relationship between the variables without the depth of establishing causality. The research adopted the survey approach for data collection using a self-administered questionnaire. The unit of analysis was the members of the top management teams. The Target Population in this study comprised all the strategic leaders in the banking sector involved in the implementation of strategy. The list of the team enumerated from the banks added to 436 for the 40 banks in Kenya.

The research approach was a census to cover all the elements in the target population. Cooper \& Schindler (2014) indicate the two conditions appropriate for a census study being that it is feasible when the population is small and necessary when the elements are quite different from each other. The size of the population of 436 suggests that a census is feasible and given the diversity of the population with all the 10 or so representatives per bank being so diverse that accurate sampling is difficult and any resulting values we calculate from the sample would be incorrect estimates of the population values (Cooper \& Schindler, 2014). Similarly prior studies with similar target group have had very low response rate (Fourie, 2007; Serfontein, 2010) and it was therefore strategic to enhance the chances of the data being of sufficcient quantity and quality by carrying out a census as opposed to a sample population. The research employed a structured self-administered electronic questionnaire, which was emailed to the respondents via the survey monkey tool and received back via the tool. A secondary data collection tool was developed for the secondary data on the Return on Assets (ROA).

To ensure higher response rate, the researcher followed up by telephone to the individual respondents whose telephone contacts could be obtained. A pilot study was carried out on a stratified sample of 30 with 2 respondents purposively selected from each of the 15 banks evenly spread across the 3 bank tiers.

The main survey was therefore sent to 406 respondents after eliminating the respondents who participated in the pilot phase of this study. The Cronbach alpha test for reliability had an index of 0.76 which is acceptable while for validity, The Kaiser-Meyer-Olkin measure of sampling adequacy (KMO) was a coefficient of $54.5 \%$ and in addition the Bartlett's Test of Sphericity is statistically significant $(\mathrm{p}<0.05)$. 
Multivariate statistical methods were used to analyze multiple variables and multiple sets of variables simultaneously (Zikmund et al., 2010). This includes multiple regression analysis in which the effects of multiple independent variables on a single, interval scaled dependent variable are investigated simultaneously.

\subsection{FINDINGS}

4.1 Effect of individual predictors (strategic leadership actions) on implementation of strategy (composite measure)

Table 1: effect of individual strategic leadership actions on the implementation of strategy

\begin{tabular}{lcc}
\hline Variable & R Square & p Value \\
\hline Strategic Direction & 0.308 & $\mathrm{p}<.001$ \\
Core Competencies & 0.188 & $\mathrm{p}<.001$ \\
Human Capital & 0.227 & $\mathrm{p}<.001$ \\
Social Capital & 0.207 & $\mathrm{p}<.001$ \\
Organizational Culture & 0.178 & $\mathrm{p}<.001$ \\
Ethical Practices & 0.229 & $\mathrm{p}<.001$ \\
Organizational Controls & 0.289 & $\mathrm{p}<.001$ \\
\hline
\end{tabular}

From the univariate analysis above, each of the strategic leadership actions individually influence the implementation of strategy.

To analyze the effects of the strategic actions applied simultaneously in the multivariate model reveals the results below:

\subsection{Multivariate model results}

Table 2: The moderated study model

\begin{tabular}{|c|c|c|c|c|c|c|c|c|c|}
\hline \multirow{2}{*}{$\begin{array}{l}\text { Model } \\
\text { Summary }\end{array}$} & \multirow[t]{2}{*}{$\mathrm{R}$} & \multirow{2}{*}{$\begin{array}{l}\mathrm{R} \\
\text { Square }\end{array}$} & \multirow{2}{*}{$\begin{array}{l}\text { Adjusted } \\
\mathrm{R} \\
\text { Square }\end{array}$} & \multirow{2}{*}{$\begin{array}{l}\text { Std. Error of } \\
\text { the Estimate }\end{array}$} & \multicolumn{5}{|c|}{ Change Statistics } \\
\hline & & & & & $\begin{array}{l}\mathrm{R} \text { Square } \\
\text { Change }\end{array}$ & $\begin{array}{l}\text { F } \\
\text { Change }\end{array}$ & df1 & df2 & $\begin{array}{l}\text { Sig. F } \\
\text { Change }\end{array}$ \\
\hline 1 & $.614^{\mathrm{a}}$ & .377 & .369 & 1.10655 & .377 & 47.554 & 2 & 157 & .000 \\
\hline 2 & $.615^{\mathrm{b}}$ & .379 & .367 & 1.10877 & .001 & .370 & 1 & 156 & .544 \\
\hline
\end{tabular}


Journal of Strategic Management

ISSN 2520-0461(Online)

Vol.2, Issue 1 No.5, pp 70 - 94, 2017

www.ajpojournals.org

\begin{tabular}{llccccc}
\hline ANOVA & & Sum of Squares & df & Mean Square & F & Sig. \\
& Regression & 116.456 & 2 & 58.228 & 47.554 & $.000^{\mathrm{b}}$ \\
& Residual & 192.238 & 157 & 1.224 & & \\
& Total & 308.694 & 159 & & 31.699 & $.000^{\mathrm{c}}$ \\
& Regression & 116.910 & 3 & 38.970 & & \\
& Residual & 191.783 & 156 & 1.229 & &
\end{tabular}

Model

$\begin{array}{lllll}\begin{array}{l}\text { Unstandardized } \\ \text { Coefficients }\end{array} & \begin{array}{l}\text { Standardized } \mathrm{t} \\ \text { Coefficients }\end{array} & \begin{array}{r}\text { Sig. } \\ \text { B }\end{array} & \begin{array}{l}95.0 \% \\ \text { Confidence } \\ \text { Interval for B }\end{array} & \begin{array}{l}\text { Collinearity } \\ \text { Statistics }\end{array} \\ \text { B } \quad \text { Std. } & \text { Beta } & \text { Lower Upper Tolerance VIF } \\ & \text { Error } & & \text { Bound Bound }\end{array}$

$\begin{array}{lllllll}(\text { Constant }) & .023 & .625 & .037 & .971 & -1.212 & 1.258\end{array}$

Strategic

$\begin{array}{lll}.836 & .178 \quad .359\end{array}$

$\begin{array}{lllll}4.695 & .000 & .484 & 1.188 & .677\end{array}$

1.476

1

Direction

Organizational

Controls

.685

$.685 \quad .157$

.334

$\begin{array}{lll}4.370 .000 & .376\end{array}$

.995

.677

1.476

(Constant)

$.288 \quad .763$

$\begin{array}{llll}.377 & .706 & -1.220 & 1.796\end{array}$

Strategic

2

Direction

$.819 \quad .181$

.352

$\begin{array}{lll}4.532 & .000 \quad 462\end{array}$

$1.176 \quad .661$

1.513

Organizational

Controls

$.701 \quad .159 \quad .342$

$\begin{array}{lllll}4.402 & .000 & .386 & 1.015 & .660\end{array}$

1.515 
Moderating

Variables

$\begin{array}{lll}-.076 & .125 \quad-.039\end{array}$

$\begin{array}{lll}-.608 & .544 & -.323\end{array}$

.171

.968

1.033

Excluded Variables

Beta In t

Sig. Partial

Collinearity Statistics

Correlation

Tolerance VIF Minimum

Tolerance

Moderating Variables

$-.039^{b}$

$-.608$

.544

$-.049$

.968

1.033

.660

The analysis for the variables that were excluded on the account of not significantly predicting the banks' effective implementation of strategy, is shown in Fig 4. The excluded variables are core competencies, human capital, social capital, organizational culture, ethical practices, and the moderating variables.

Table 3: The Excluded Variables

\begin{tabular}{|c|c|c|c|c|c|c|c|}
\hline \multirow[t]{2}{*}{ Excluded Variables } & \multirow{2}{*}{$\begin{array}{c}\text { Beta } \\
\text { In }\end{array}$} & \multirow[t]{2}{*}{$\mathbf{t}$} & \multirow[t]{2}{*}{ Sig. } & \multirow{2}{*}{$\begin{array}{c}\text { Partial } \\
\text { Correlation }\end{array}$} & \multicolumn{3}{|c|}{ Collinearity Statistics } \\
\hline & & & & & Tolerance & VIF & $\begin{array}{l}\text { Minimum } \\
\text { Tolerance }\end{array}$ \\
\hline Core Competencies(CC) & $.028^{\mathrm{c}}$ & .331 & .741 & .026 & .543 & 1.841 & .543 \\
\hline Human Capital(HC) & $.086^{\mathrm{c}}$ & .947 & .345 & .076 & .481 & 2.077 & .481 \\
\hline Social Capital(SC) & $.128^{\mathrm{c}}$ & 1.624 & .106 & .129 & .634 & 1.578 & .596 \\
\hline $\begin{array}{l}\text { Organizational } \\
\text { Culture }(\mathrm{OCu})\end{array}$ & $.044^{\mathrm{c}}$ & .523 & .602 & .042 & .570 & 1.754 & .570 \\
\hline Ethical Practices(EP) & $.145^{\mathrm{c}}$ & 1.766 & .079 & .140 & .582 & 1.719 & .559 \\
\hline Moderating Variables & $-.039^{c}$ & -.608 & .544 & -.049 & .968 & 1.033 & .660 \\
\hline
\end{tabular}

As Fig 3 indicates, regression modeling was used to test the effect of several predictor variables on a bank's effective implementation of strategy (using a composite of financial and nonfinancial measurement). Regression analysis was used to test if several predictor variables significantly impact on a bank's effective implementation of strategy. The results of the regression indicated that two predictors explained $37.7 \%$ of the variance $\left(\mathrm{R}^{2}=.377, \mathrm{~F}(2,159)\right.$ $=47.554, \mathrm{p}<.001)$. It was found that "Strategic Direction" significantly predicted the banks' 
effective implementation of strategy $(\beta=.836, \mathrm{p}<.001)$. It was also found that "Organizational Controls" significantly predicted the banks' effective implementation of strategy $(\beta=.685$, $\mathrm{p}<.001)$.

The composite regression model takes the form:

$\mathrm{y}_{\mathrm{i}}=\beta_{0}+\beta_{1} \mathrm{x}_{\mathrm{i} 1}+\ldots+\beta_{\mathrm{p}} \mathrm{x}_{\mathrm{ip}}+\varepsilon_{\mathrm{i}}$

where:

$\mathrm{y}_{\mathrm{i}}=$ the value of the $\mathrm{i}^{\text {th }}$ case of the dependent scale variable

$\mathrm{p}=$ the number of predictors

$\beta_{\mathrm{j}}=$ the value of the $\mathrm{j}^{\text {th }}$ coefficient, $\mathrm{j}=0, \ldots, \mathrm{p}$

$\mathrm{x}_{\mathrm{ij}}=$ the value of the $\mathrm{i}^{\text {th }}$ case of the $\mathrm{j}^{\text {th }}$ predictor

$\varepsilon_{\mathrm{i}}=$ the error in the observed value for the $\mathrm{i}^{\text {th }}$ case

The regression model for the influence of the seven predictor variables on the strategy implementation is as follows:

$\mathrm{SI}=0.023+0.836 * \mathrm{SD}+0.685 * \mathrm{OCo}$.

where:

SI $=$ Strategy Implementation

$\mathrm{SD}=$ Strategic Direction

$\mathrm{OCo}=$ Organization Controls

From the excluded variables in the Moderated Study Model in Fig 4., it is observed that if the level of statistical significance in the model was relaxed to $10 \%$, then Ethical Practices, becomes a statistically significant variable in terms of influence on the dependent variable, $p$ $=0.079$.

\subsection{RECOMMENDATIONS}

Of the 7 actions characteristic of strategic leadership, the survey reveals that determining strategic direction' directly influences the effective implementation of strategy in the commercial banks in Kenya. It is important for the leadership and in particular the CEO communicates with clarity, the strategic direction of the organization if it is to achieve its strategic objectives of remaining competitive in the market. Similarly establishing a balance between strategic and financial controls has a direct influence on the implementation of strategy. A strategic leader creates wealth by striking a balance between the constraining influence of financial controls and the long term focus of the strategic controls.Banks should use a strategic tool like the Balanced Scorecard to achieve the balance between strategic controls and financial controls. The balanced scorecard can be used to reduce strategic 
decoupling and achieve global harmonized strategy especially for the banks that have subsidairies operating outside Kenya where they have to balance the local interests against the global targets set by the parent in Kenya.

Areas for further research include extending the study to include other staff other than the top management team, especially those below the c-suite and the members of the board of directors, which would enrich the study and possibly generate different outcomes. The study developed a data collection tool for the primary data and another for the secondary data. These instruments could be tested and adopted for use in other contexts, other sectors, or other regions where some attributes may be different from those used for the banking secotr in Kenya. The findings and conclusions are dependent on the approach adopted. This study adopted the quantiative research design and future research could adopt a mixed quantitative and qualitative approach and compare and contrast the findings to those generated from this quantiative approach.

\section{REFERENCES}

Adler, P. S., \& Kwon, S.-W. (2002). Social Capital: Prospects for a New Concept. Academy of Management Review, 17-40.

Allio, M. K. (2005). A Short, Practical Guide to Implementing Strategy. Journal of Business Strategy, 26.

Arnaud, A., \& Schminke, M. (2012). The ethical climate and context of organizations: A comprehensive model. Organization science, 23(6), 1767-1780.

Barney, J. B. (1986). Organizational Culture: Can It Be a Source of Sustained Competitive Advantage? The Academy of Management Review, 11(3), 656-665.

Bass, B. M. (2007). Executive and Strategic Leadership. International Journal of Business, $12(1), 33-52$.

Boal, K. B., \& Hooijberg, R. (2000). Strategic Leadership Research: Moving On. Leadership Quarterly, 11(4), 515-549.

Bossidy, L., \& Charan, R. (2002). Execution: The discipline of getting things done. London: Random House Business Books.

Candido, C. J., \& Santos, S. P. (2015). Strategy Implementation: What is the failure rate? Journal of Management and Organization, 21(2), 237-262.

Carter, S. M., \& Greer, C. R. (2013). Strategic Leadership: Values, Styles, and Organizational Performance. Journal of Leadership \& Organizational Studies, 20(4), 375-393. 
Cater, T., \& Pucko, D. (2010). Factors of effective strategy implementation: Empirical evidence from Slovenian business practice. Journal for East European Management Studies, 15(3), 207-236.

CBK. (2015a, July 4). CBK. Retrieved from Central Bank of Kenya website: https://www.centralbank.go.ke/images/docs/legislation/Prudential\%20GuidelinesJanuary\%202013.pdf

CBK. (2015b, July 4). CBK. Retrieved from Central Bank of Kenya website: https://www.centralbank.go.ke/images/docs/legislation/risk-management-guidelinesjanuary-2013.pdf

CBK. (2015c). CBK. Retrieved from Central Bank of Kenya website: https://www.centralbank.go.ke/images/docs/Bank\%20Supervision\%20Reports/Annua 1\%20Reports/2014BSAnnualReport.pdf

CBK. (2015d). Bank Supervision Department Annual Reports. Retrieved from Central Bank of Kenya website: https://www.centralbank.go.ke/images/docs/Bank\%20Supervision\%20Reports/Annua $1 \% 20$ Reports

CBK. (2017, 04 29). Retrieved from http://www.centralbank.go.ke

Cooper, D. R., \& Schindler, P. S. (2014). Business Research Methods (Twelfth ed.). Boston: Irwin McGraw Hill International.

Duursema, H. (2013). Strategic Leadership: Moving beyond the leader-follower dyad. Rotterdam: Erasmus University Rotterdam.

Dyer, J. H., \& Singh, H. (1998). The relational view: Cooperative strategy and sources of interorganizational competitive advantage. Academy of Management Review, 23(4), 660-679.

Ehlers, M., \& Lazenby, J. (2004). Strategic Management: Southern African Concepts and Cases. Pretoria: Van Schaik.

Elenkov, D. S., Judge, W., \& Wright, P. (2005). Strategic Leadership and Executive Innovation Influence: An International Multi-Cluster Comparative Study. Strategic Management Journal(26), 665-682.

Finkelstein, S., \& Hambrick, D. C. (1990, September). Top-Management-Team Tenure and Organizational Outcomes: The Moderating Role of Managerial Discretion. Administrative Science Quarterly, 35(3), 484-503.

Finkelstein, S., \& Hambrick, D. C. (1996). Strategic Leadership: Top executives and their effects on organisations. Minneapolis/St. Paul: West Publishing Company. 
Fourie, B. (2007). The role of strategic leadership in strategy implementation. Johannesburg: Unpublished $\mathrm{PhD}$ thesis.

Gao, S., Xu, K., \& Yang, J. (2008). Managerial ties, Absorptive Capacity and Innovation. Asia Pacific Journal of Management, 25, 395-412.

Goldman, E. F., \& Casey, A. (2010). Building a culture that encourages strategic thinking. Journal of Leadership and Organizational Studies, 17(2), 119-128.

Grant, R. M. (1991). The resource-based theory of competitive advantage: Implications for strategy formulation. California Management Review, 33(3), 114-135.

Grant, R. M. (2008). Contemporary Strategy Analysis. Malden, Massachussetts: Blackwell pubilshers Inc.

Hagen, A. F., Hassan, M. T., \& Amin, S. G. (1998). Critical Strategic Leadership Components: An Empirical Investigation. SAM Advanced Management, 63(3), 39-44.

Hallen, B. J., \& Eisenhardt, K. M. (2012). Catalyzing strategies and efficient tie formation: How entrepreneurial firms obtain investment ties. Academy of Management Journal, 55(1), 37-70.

Hambrick, D. C., \& Mason, P. A. (1984). Upper Echelons: The Organization as a Reflection of its Top Managers. The Academy of Management Review, 9(4), 193-206.

Herrmann, P., \& Nadkarni, S. (2014). Managing Strategic Change: The Duality of CEO Personality. Strategic Management Journal, 35, 1318-1342.

Hitt, M. A., Bierman, L., Shimizu, K., \& Kochhar, R. (2001). Direct and moderating effects of human capital on strategy and performance in professional service firms: A resourcebased perspective. Academy of Management Journal, 44(1), 13-28.

Hitt, M. A., Bierman, L., Uhlenbruck, K., \& Shimizu, K. (2006). The importacne of resources in the internationalization of professional service firms: The good, the bad and the ugly. Academy of Management Journal, 49, 1137-1157.

Hitt, M. A., Ireland, R. D., \& Hoskisson, R. E. (2013). Strategic Management: Competitiveness \& Globalisation (11 ed.). Stamford: Cengage Learning.

Hitt, M., Ricart, J. E., \& Nixon, R. D. (1998). New managerial mindsets: Organizational transformation and strategy implementation. New York: John Wiley \& Sons.

House, R., \& Aditya, R. (1997). The social scientific study of leadership: Quo vadis? Journal of Management, 23, 409-473. 
Hrebiniak, L. (2006). Obstacles to Effecitive Strategy Implementation. Organizational Dynamics, 35(1), 12-31.

Kaplan, R. S., \& Norton, D. P. (1992). The Balanced Scorecard - Measures that Drive Performance. Havard Business Review, 71-79.

Kaplan, R. S., \& Norton, D. P. (1996). The Balanced Scorecard : Translating Strategy into Action. Boston, Massachusetts: Havard Business School Press.

Kaplan, R. S., \& Norton, D. P. (2001a). The Strategy-focused organisation: How Balanced Scorecard Companies thrive in the new business environment. Boston, MA: Havard Business School Press.

Kaplan, R. S., \& Norton, D. P. (2001b). Transforming the balanced scorecard from performance measurement to strategic management : Part 1. Accounting Horizons, 15(1), 87-104.

Kim, S. K., Arthurs, J. D., Sahaym, A., \& Cullen, J. B. (2013). Search behaviour of the diversified firm: The impact of fit on innovation. Strategic Management Journal, 34(8), 999-1009.

Klein, A. (2008). Organizational culture as a source of competitive advantage. E-Leader Bangkok, 1-10.

Kotter, J. P. (2001, December). What leaders really do. Havard Business Review, 1-12.

Kuchio, J. J. (2012). Analysis of the role of strategic leadership in Strategy Implementation in Kenyan Private Universities: A case study of Kabarak University. Nakuru.

Lear, L. W. (2012). The Relationship between Strategic Leadership and Strategy Alignment in high performing companies in South Africa. Johannesburg.

Lipton, M. (1996). Demystifying the Development of an Organization Vision. Sloan Management Review, 37(4), 83-93.

Lussier, R., \& Achua, C. (2007). Effective leadership. Ohio: Thomson Higher Education .

MacKay, R. B., \& Chia, R. (2013). Choice, chance, and unintended consequences in strategic change: A process understanding of the rise and fall of NorthCo Automotive. Academy of Management Journal, 56(1), 208-230.

Mankins, M. C., \& Steele, R. (2005, July-August). Turning Great Strategy into Great Performance. Havard Business Review. 
Mapetere, D., Mavhiki, S., Nyamwanza, T., Sikomwe, S., \& Mhonde, C. (2012). Strategic Role of Leadership in Strategy Implementation in Zimbabwe's State Owned Enterprises. International Journal of Business and Social Sciences, 3(16), 271-276.

Mkansi, M., \& Acheampong, E. A. (2012). Research Philosophy Debates and Classifications: Students' Dilemma. The Electronic Journal of Business Research Methods, 10(2), 132140.

Mollick, E. (2012). People and process, suits and innovators: Individuals and firm performance. Strategic Management Journal, 33, 1001-1015.

Ndofor, H. A., Sirmon, D. G., \& He, X. (2011). Firm resources, competitive actions and performance: Investigating a mediated model with evidence from the in-vitro diagnostics industry. Strategic Management Journal, 32, 640-657.

Nohria, N., \& Beer, M. (2000, May-June). Cracking the Code of Change. Havard Business Review.

Pearce, J. A. (2013). Using social identity theory to predict managers' emphases on ethical and legal values in judging business issues. Journal of Business Ethics, 112, 497-514.

Pearce, J. A., \& Robinson, R. B. (2011). Strategic Management: Formulation, Implementation, and Control. New York: Mc Graw Hill/Irwin.

Priem, R. L., Lyon, D. W., \& Dess, G. G. (1999). Inherent Limitations of Demographic Proxies in Top Management Team Heterogeneity Research. Journal of Management, 25(6), 935-953.

Rajasekar, J. (2014). Factors affecting Effective Strategy Implementation in a Service Industry: A Study of Electricity Distribution Companies in the Sultanate of Oman. International Journal of Business and Social Science, 5(9), 169-183.

Rowe, W. G. (2001). Creating wealth in organizations: The role of strategic leadership. Academy of Management Executive, 15(1), 81-94.

Rowe, W. G. (2001). Creating Wealth in Organizations: The Role of Strategic Leadership. The Academy of Management Executive (1993-2005), 15(1), 81-94.

Sanders, T. T., \& Davey, K. S. (2011). Out of the Leadership Theory Jungle: A proposed MetaModel of Strategic Leadership. Allied Academic International Conference (pp. 41-46). Orlando, Florida: DreamCathers Group LLC.

Saunders, M., Lewis, P., \& Thornhill, A. (2014). Research Methods for Business students (5th ed.). London: Prentice Hall. 
Schwartz, M. S. (2013). Developing and sustaining an ethical corporate culture: The core elements. Business Horizons, 56(1), 39-50.

Serfontein, J. J. (2010). The impact of strategic leadership on the operational strategy and performance of business organizations in South Africa. $\mathrm{PhD}$ Thesis, University of Stellenbosch, Business Management .

Sila, H. M., \& Gichinga, L. (2016). Role of Strategic Leadership on Strategy Implementation in Public Universities in Kenya- A Case Study of JKUAT Main Campus. International Journal of Innovative Research, 5(6), 216-239.

Sirmon, D. G., Hitt, M. A., \& Ireland, R. D. (2007). Managing Firm Resources in Dynamic Environments to create value: looking inside the Black Box. Academy of Management Review, 32(1), 273-292.

Sonenshein, S., \& Dholakia, U. (2012). Explaining Employee Engagement with Strategic Change Implementation: A Meaning-Making Approach. Organization Science, 23(1), $1-23$.

Srivastava, S. C. (2005). Managing Core Competence of the Organization. Vikalpa, 30(4), 4963.

Waweru, N. M., \& Kalani, V. M. (2009). Commercial Banking Crises in Kenya: Causes and Remedies. African Journal of Accounting, Economics, Finance and Banking Research, 4(4).

Zaleznik, A. (1992, March - April). Managers and Leaders: Are they different? Havard Business Review, 1-12.

Zikmund, W. G., Babin, B. J., Carr, J. C., \& Griffin, M. (2010). Business Research Methods (8th ed.). Mason, Ohio: South-western Cengage Learning. 